$\operatorname{sig}$

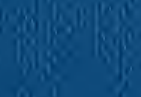
Q6.

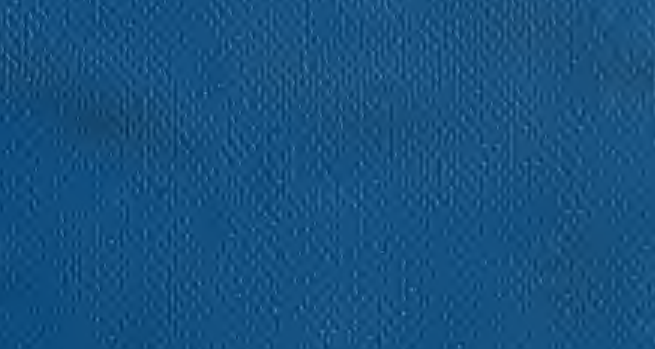

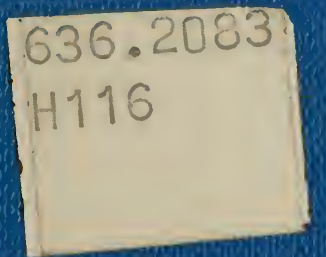

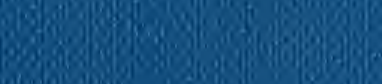

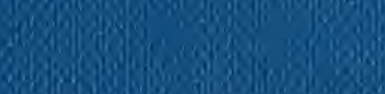
G.

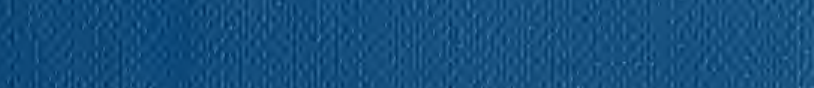
3. 


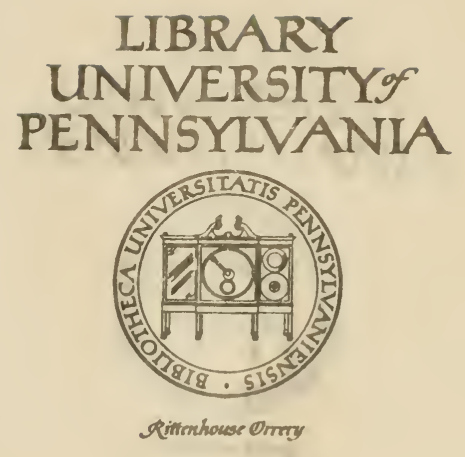

FAIRMAN ROGERS COLLECTION ON

\section{HORSEMANSHIP}




\title{
DEHORNING CATTLE,
}

\section{CASTRATION OF BULLS,}

\author{
CATTLE SHEDS,
}

AND

\section{WARM DRINKING WATER,}

B'

H. F. HAAFF,

IEMANS GROVE, HENRY COUNTY, ILLINOIS.

P. O. ATKINSON.

I L L U T R A T E D.

C H I CA GO :

Rayd, IcNally \& Co., Printers axd Engravers,

148 to 151 Monroe Street.

1686.

New Bolton Center 
NEW EOLTON CENTER

636.2083

H116

Coptright, 136, ву

H. H. HAAFF.

Heman's Grove, Gexry County, Ill. 


\section{RESPECTFULLY DEDICATED}

TO THE

\section{FORTY FARMERS,}

AND OTHERS,

WHO FACED THE BLIZZARDS OF FOUR JANUARY DAYS, IN 1886, TO TESTIFY IN

MY BEHALF,

BY THE AUTHOR. 
Digitized by the Internet Archive in 2009 with funding from

Lyrasis Members and Sloan Foundation 


\section{PREFACE.}

Gentle Reader: We sometimes have to do those things we would not; we then proceed to make a virtue of the necessity. The writer has been beset and hesieged by hundreds of letters from Maine to Mexico, asking for information on the subject of " dehorning cattle." He has been heralded from one end of the Republic is the other as the "Great Dehorner," etc. He has successfully treated his own cattle, of all ages and sizes, for years. He has instructed many others in the art. He talked to the people time and again and never failed to convert his hearers. He has written on the matter in a score of papers and demonstrated the thing again and again in hundreds of cases; perhaps, therefore, if his experience is placed in book form he may not be open to the charge of pedantry in so doing. May the time come, and come speedily, when a horned brute will be as scarce as a Mulley is now. May the time soon come when dehorning will be as common as castration now is. 



\section{DEHORNING CATTLE.}

CHAPTER I.

\section{HOW I CAME TO DEHORN CATTLE.}

"How came you to dehorn your cattle?" said a friend to the writer not long since. "You are made notorious everywhere by this practice. You are the best advertised man in the United States to-day, except Barnum and Jay Gould, and I'd like to know how you came to do it?" Well, if you care to hear the story, here goes: From a boy of thirteen my dream was to own a big farm, and lots of cattle and horses. I had an idea that 500 cattle and 100 horses was about as tall a hemlock as any one man could climb; you see that was before the days of the plains. But I had to work until I was forty years old at my profession before I was able to own a farm-in the meantime I became a most enthusiastic book farmer (I lost all that poetry, however, some years since). I had a standing aversion to horns. From the rescuing of a neighbor; from leaping from a second-story window en déshabillé to save another neighbor, pinioned by a cow to the earth; from that to the bedside of my own disabled wife, injured in the same way, then to a hired girl stripped and torn, and then to the loss of my own clothes by a cold horn run up my back, and a suit for several thousand dollars because (they said) I "kept an ugly bull;" from these to the goring of my own colts, hogs and cattle by horns, there was, I say, from all these, but one issue: "Horns must go." The ancient Roman adopted as his motto: "Carthago delende est." Mine became: "Cornu delende est." I hated horns, denounced horns as horrible excrescences, devilish appendages, abominable pro- 
tuberances, unnecessary additions, and declared that they or I must go. I run to hogs and neglected cattle. Quit hogs at 1,000 because they would not lay the dirt the right way. I run to horses, had several killed by kicking, strapped a short piece of chain to the fetlock joint of the kicker and stopped that loss, only to grunt audibly when any "chain" brutes came around at their display of apparent inconvenience, and then I went into cattle again and began to think. I downed the "best cow," roped her, sent all the boys off but one, took my saw and scalpel, and began. I can hear her groans yet. Ge Whillikins! but didn't the blood fly when 1 ran the knife around that horn at the base? I can taste it yet. I was now in for it, fairly elected, and my blood was up, and if that infernal old rip of a cow had had ten lives I would have sacrificed them all to study my way out-not in anger, not in malice, not for fun, oh no; but solely and surely to know if we had to live on and on and endure the soul-harrowing scenes daily witnessed in my yards. Well, the knifing over, we used the saw and cut out the horns, and used the shears, and pared up the skin and put some stitches in, and turned her loose. Presto, " a beautiful Mulley;" but oh, my my, wasn't there a sore head? However, in a few weeks "Old Gray" was well, gave just as much milk, and was gentle as a lamb ever after, and she lived for years the "best cow." This was dehorning under difficulties, and I don't care to face the family again in such a condition and with such feelings. Is there no way out of all this? said I; and then, after further trouble and loss by horns, in sheer despair I put up a brute and sawed off her horns half way down; that was awful! awful! but not so bad as before, and so I solemnly concluded to kill one animal in order to find out all there was to it by suwing off her horns close to the head. I watched my chance; took an ugly one, of course-one that was ready for the beef barrel. Off went the horns, close up. I turned him loose, expecting to see him drop, or soon bleed to death. There was a lot of timothy hay in the yard; do you think, that infernal brute shook his head and went to eating. I was astounded. There I had been covered with blood in my first case, and had it squirted by the quart in the second and third cases, and now when I dared to cut close to the head the 
wretched brute stopped bleeding and went to eating. I fairly whooped and yelled that "the devil was to pay and no pitch hot;" that the evil one was in the cattle anyhow. I kept on thinking. I examined heads. I tried another in a few days with like results. I saw it all at last, the reason, plain, plain. Wonder I had not thought it out before. I became a dehorner at once. People called me "mad," "a brute," "a little off;" said I ought to be hung; proposed to mob me; and said one: "I'll head the crowd;" but here I am now, and this is just how I " came to do it." 


\section{CHAPTER II.}

\section{THE ADVANTAGES.}

"Dehorning seems to gentle my cattle. They ain't half as bad or ugly-like as they used to be." So said a farmer who had learned the art of me. Precisely so. "Well, why is it ?" I'll tell you. The cattle know their power with horns just as well as you do, and they know, too, when that power is gone. That reminds me of my neighbor, Bill Taber, of Whiteside County. Mr. T. had a Holstein bulla big fellow-a ton or more of bull; a man-killer. I dehorned him. A few mornings after, Mr. T.'s little boy was seen leading the bull down to water by the ear. Mr. T. yelled, and ran out, when the boy cried, "Oh, hold on, pa; don't get scared! the calves drive old Dick now." And so they did. Like Sampson, old Dick knew his strength, or rather his power for mischief, was curtailed. I bought Dauphin 20th, an imported Hereford bull, of A. A. Crane \& Co., for a very low price. He, too, was a man-killer. My little boy led him, after dehorning, thirty miles by a tie strap. He weighed 2,300 pounds; dehorning settled him. You ask for the advantages of dehorning. Well, let me couple them together.

If dehorning should become a uniform-a common-practice, there would follow a saving of :

1st.-200 lives of human beings in the United States each year.

2nd.-The lives of 100,000 cattle and horses each year, not to mention sheep and hogs.

3rd.- Nearly all loss of calves by abortion.

4th.-One quarter of our winter feed for cows and stock cattle. jth.-One half our shed room.

bith.-All the manure now wasted around sheds and stables. 7th.-All loss in shipping cattle.

Now, my friend, what have you to say against me and my position? I have stood threats, and calumny, and abuse, and prosecution, and 
persecution, and boycotting; now what have you to say? Nothing but "god-speed and go-ahead."

"But please explain why these results will follow."

Well, then, first. Allowing that there are two hundred deaths by horns yearly, that would give only ten as the quota for Illinois, and that is under the mark; that is to say, the average would be one death to each 300,000 of population (nearly). The loss of stock no man can more than estimate; but when one considers that every farmer almost loses animals right along by horns, it will be seen that the estimate is not too large.

The saving on feed comes, of course, because cattle without horns will pack and keep warm and quiet, and because warmth saves feed. I have carefully tried the matter for three winters, and can say that one-quarter my hay is saved to me in this way. A friend who tried warm water on a herd of 400 short-horns, tells me that warm water alone saved more than one-tenth of his feed. In the interest of adranced agriculture, these things are worth considering.

As to shed room, I keep 250 head of cattle in a shed $30 \times 160$ feet. Does anyone suppose that one-half that number of cattle can be kept in that shed with horns? No; not 100 head.

As to the manure question, I simply say that cattle without horns will all, during cold weather, seek and find a shed. They will eat and at once go to a shed, and if, as I do, and it may always be done, the shed is boarded up on all four sides (save one or two openings on the south) and there is warm water inside, I say your manure will be there-housed and pure-just what you want for corn.

As to shipping cattle, I will repeat the statement made to me by $\approx$ representative of the Drover's Journal recently. Said he: "They have tried all kinds of patents and nothing yet found but bruises the cattle, and there is but one way out-but one solution of the question-and that is a car with no protuberances and no horns on the cattle." Said a ranchman recently: "Give me the losses on the plains by horns and I will outrank a V'anderbilt in wealth in a very short time." Sald another: "Give me the losses by horns in shipping, and I will rank with you." And I will add, "Give me the losses by horns 
in the States alone, on the small farms and at the houses of everyday people, and I will become a Croesus in wealth in ten years." If, then, I can help to save the lives of men and cattle, the feed and the manure, what better work can one do for his day and generation?

\section{LOSSES OF CALVES BY ABORTION.}

I raise a hundred or more calves yearly. So great have been my losses that, like my neighbors, I have been inclined to "quit and buy my calves," but the price of a good calf - a good calf-is nearly equal to that of a yearling, and principally because the losses are so great. On the plains I am assured by competent judges that men lose on the big ranches one-half their calves, and one gentleman said: "They may say what they please, I know it to be so."

Consider for a moment that the calf-the foetus-lying in the womb of its mother is constantly exposed to horn thrusts. All other injuries are provided against (save the toe of the milkman's boot), but the horn of the passing cow means death to the calf. If you will only just stop, stop and think on this for a moment, there right up under and forward of the udder, a little to the right, lies the foetus. For almost twenty-four hours the mother is in danger of a passing blow, and a very slight blow with the end of the horn is enough. The only wonder is that we do not loose all our calves. Don't talk to me about "its being catching," and "you must bury the placenta," and "you must not yell or scare the brute," etc. All very well, but cows don't lose their calves without help. From a loss of twenty-five in one year with horns, I dropped to three the next year with no horns. Comment is not needed. The undertaking to keep 500 cattle over winter in our climate with horns in one herd is what can't be done without great loss. Dehorn them, and it can be done, and of all ages and sizes, too. How cattle do hate each other. How they do stand on their dignity. How utterly regardless they are of all but self. What a lesson, what a sermon they continually preach us on forbearance. 


\section{CHAPTER III. \\ ORIGIN OF POLLED CATTLE.}

The study of this branch of the subject is obriously in part speculative; but there is no reasonable doubt to question the fact that by a careful polling of our calves we should, in a very short time, have any breed of cattle polled, for this is undoubtedly true, that as like begets like, so any organ not provided with full and direct arterial circulation is liable at any time to be not produced, and as horns have only capillary circulation, they are fit subjects for the illustration of this principle. So, too, in the case of geese kept in mountain ranges, which lose the webs of their feet and have feet without webbed toes, or as in case of careful breeding, as is shown in bull.dogs with tails bred to stubs. Those are parts, it will be seen, having the lowest circulation. Horns are especially liable to this rule, for in the older animal the periosteum or membrane around the bone-horn is not thicker than paper. Doubtless, too, careful breeding has given us the well-developed Galloway, and polled Angus and Norfolk polled cattle, while it is a well-known fact that some of the polled herds had horns not a hundred years since.

As an instance of like producing like, the writer had, a few years since, among a thousand hogs, one Chester White sow that was crosseyed. Thinking to try an experiment, he watched her litters of pigs, and found, finally, a boar pig and two sow pigs similarly marked. Careful inbreeding of them gave, in a few generations, a regular lot of cross-eyed pigs, until the experiment liked to have proved scrious, her pigs being so cross-eyed that some of them, as one of my boys said, had to look seven ways for Sunday and all ways for their food. Or, like the Jersey stock once introduced into your herd, and you can trace the thirty-second part thereof in color and characteristics. We can dehorn our calves and get a Holstein or Short-horn breed of polled cattle in six crosses, but it will take sixteen crosses for the Hereford's, in my judgment. 


\section{CHAPTER IV.}

\section{THE VETERINARY SIDE OF THE SUBJECT.}

"God put them horns there," says one, "and you have no business to remove them." "You are engaged in poor business trying to improve on nature." Just so-just so, my friend-just so; and God put that wart on the end of your nose, and you-but I forbearit's too personal. And now as to improving on nature-why, that is just what we are all at.

We trim our trees, pare our nails, remove nature's corns and excrescences of all kinds, my friend, including horns, just because we find it to be profitable to do so. We castrate and spay cattle, and ring the pigs' noses, and do a thousand things against nature that our judgment advises us to do.

Is it not a little remarkable that none of the works on veterinary science, and none of the veterinary surgeons themselves, pretend to give, or do give any particular account of the anatomy of the bovine's head as related to the horns and the parts connected? Even the French writer, the great Cheveaux, in his comparative anatomy, throws little light on the question. None of the encyclopedias, save Britannica, tell us more than that there are different kinds of horns in different animals, and that the horns of the bovine are hollow. There is no doubt at all that the so-called disease, "Hollow Horn," is nothing more nor less than horns that have been chilled; that is to say, the horn is composed of four parts: the bone-horn, the periosteum or membrane around the bone-horn, the shell, and the matrix at the base of the shell. These four parts constitute the make-up of the horn, and in dealing with the question of hollow horn as a disease, it must be borne in mind that all cattle horns are hollow. That is to say, in the calf the embryo horn is a button of cartilage. It is loose for several weeks; then it begins to connect with the frontal bone of the forehead. At a year old it begins to become vascular- 
that is, porous-and at one year (and sometimes sooner) it develops a hollow at the base, and thence forward is always hollow. There is no "pith," and no such thing as "pith," and no marrow in or to a horn. There is no such thing as pith or core; it is "bone-horn." There is no feeling to either the skull or to the bone-horn, and there is no feeling to cartilage, of which bone is formed; there is no marrow inside the bone-horn, and there is no marrow inside any of the frontal bones of the head or in the "frontal sinuses" (a sinus is a bay or hollow). Now then, it will be seen at a glance that there can be no such disease as the "hollow horn." What is it, then? Why, simply this: When a bovine gets chilled, it begins to freeze first up at the horn tips; that thin membrane between the shell-horn and the bone-horn begins to chill first, and as the cold extends along down to the head the matrix also chills, and then when the brute begins to warm up there is, of course, an inflammation just as with a frozen toe when it thaws out. Now if you bore into that horn and give "vent" to that inflammation, your hollow horn disease stops; but a better way is to cut off the tip of the horn a little way down and let the pus escape, and a much better way is to dehorn the animal. The Montana cattle men understand this, and they will tell a droopy horn brute early; and they say, "take one that has not eaten anything for sometime and cut off the tip of the horns and let out the offensive matter, and he will go to eating at once." And they also say (for - several of them have been to see me on this matter) that "unless you do give such a horn 'vent,' the animal will do nothing that whole season."

Plenty of men from the plains have gone home from me after full explanation and instructions to "put dehorning into practice the same time that we castrate our calves." This is what Dr. Law says: "I could wish that dehorning of calves might become as common as castration is now." What is to prevent? Nothing. Now, as will be seen, the only feeling the brute experiences in removing the horn is when either the periosteum or the matrix is disturbed, and in the next chapter is giren a full and extended account of how dehorning should be done, and how to operate on all ages and conditions. 
Among all the veterinarians not a man could be found to give any rational explanation of this process. The nearest that came to it were Di. R. J. Withers and Dr. Joseph Hughes, of the Chicago Veterinary College. The former had in his youth seen a few cases where ugly hrutes, or brutes with one horn lost, had been operated upon. The latter had seen it practiced, when a boy, on catt'e crossing the channel from Ireland to England, because if not done, cattle were rery liable to do terrible damage with their horns en voyage. The doctor said in testifying that he had seer. them ripped half way around the body. The vriter metan old Scotchman who recollected that, in his youth, in Scotland and the North of Ireland, dehorning was practiced "to gentle the cattle," but an act of Parliament was passed prohibiting it (now happily done away with).

Perhaps it ought to be stated here that the author has paid the full penalty for the privilege of writing this little book, by standing his trial for four days against all that vindictiveness and corporate influence could do to convict him of being guilty of cruelty to animals; that he has fully vindicated the practice of dehorning, and also vindicated his own position in connection therewith; but there were years of ostracism, and that kind of crawling sensation one feels when approaching a brute in the manner of many (mistaken) good people towards himself. There are many persons who have come and made the "amende honorable" by apologizing to the writer personally, and many others by letter.

Consider for a moment the relation of the several parts of the bovine head. The top is composed of this frontal bone and various cross-bones for strength, and down underneath all is the parietal bone of the bram.

Now, the suture, as it is called, runs crossways in the human skull, and in the horse skull, ton, but in the cow it runs the whole length of the face, from top to bottom. This understood, explains away the false sympathy one feels when comparing dehorning with a cow whose horn is knocked off, for in the latter ease the pain is not so much on the ugly bloody horn-bone that is left (although it looks as though it was very painful), but the pain is at the brain, because that blow which knocked off the shell-horn at the same time opened the suture 
more or less, and congested the brain at the point where you aim to sloot a brute, and where both the bones are united. The blow tended to separate the brain along the suture, and hence the agony. Take an old cow skull and separate it up and down in front (there is a place to do it, and that is at the suture). Now recollect that when the brute lived, the parts were more or less soft, and a blow on the horn was awful, because it tended to divide the brain in the middle. To cut off a horn would not hurt one-hundredth part as much because you only divide the thin membrane.

The following letter, written the writer after his trial and discharge, is here given with the remark that Dr. Cutts and the writer were the first to agree upon this question, although the doctor said frankly: "I have changed my mind upon this matter after reflection." This, too, was the writer's position after long experience in dehorning, for he now knows that dehorning properly done is not very painful.

Hox. H. H. HAAFF:

Dear Sir: In the suit of the State Humane Society against yourself for cruelty to animals in sawing off their horns, recently on trial in this city, the testimony of experts in behalf of the prosecution went to slow that the operation was one of great cruelty, inflicting severe pain upon the animal, entirely disproportionate to the benefits expected to be derired from it. If this is true, the case should have been prosecuted and an attempt made to put a stop to the practice. But the overwhelming weight of testimony on your side from farmers and others accustomed to the care of cattle, who had either secn the operation of dehorning or hal performed it themselves, that the animals did not apparently suffer much pain at the time or afterward; that they manifested no symptoms of shock, but partook of food and water immediately; that in milch cows the secretion of milk was not in the slightest degree diminished or changed, goes very far to prove that the operation is not so severe as has been generally supposed, and that the testimony on the opposite side was given more as the result of preconceived opinions and theories rather than from actual study and observation.

It is quite possible that the nervous system of animals becomes less and less sensitive to pain in proportion as they descend to lower grades, but of that we can have no proof, except from the behavior of the animal itself. Assuming in this case that there is no difference in sensibility to pain, it becomes important to consider the anatomical cons'ruction of the horn, in relation to its supply of nerves and blood vessels. It may be stated as a rule, that while the nerves 
that are sensitive to pain are more generally distributed over the surface of the body, they are distributed with increased supply to parts that undergo rapid waste and repair, and are diminished where these processes take place more slowly. The sime statement may be made with regard to the blood vessels which supply the materiais for mutrition. No physiologist will assert for one moment that there is any very considerable circulation of blood within the horn or any active process of waste and repair going on there to require such a circulation. It would be to contradict all the results of observation and experience. On the contrary, the circulation is extremely small and the changes are very slow, so that we might inferentially fiom these facts alone come to the conclusion that the nervous supply was very limited also. It cloes not change this conclusion if we assume that the function of nutrition is controlled by the sympathetic nerve, which is not a nerve of sensation; that would of itself render the supply of sensitive nerves still less vecessary or important.

The liorn of an animal is its weapon for attack or defense, subject to rude shocks and heavy strains and to oceasional loss by violence. It would seem improbable from the very nature of its functions that it should be endowed with a great degree of nervous sensibility, which would be a disadvantage rather than an advantage to it.

No one can for a moment suppose that there is any susceptibility to pain in the outside shell of the horn. A blow upon it may, by jar or concluction, affect the more sensitive parts at its base; but it is itself as absolutely incap. able of sensation as is the hair, or the free border of the nails; belonging as it dues to the same epidermic structures that contain neither nerve or blood vessels, consisting wholly of exuded or formed matter, that unclergoes no further changes than to be cast off. The central part of the horn in young life consists entirely of cartilage which is separate and independent of the frontal bone. This becomes by age converted into true bone, by the same process that takes place in fœtal cartilage, viz.: the deposition in it of mineral matters, chiefly salts of lime. Neither cartilage or bone are sensitive tissues; that is, they are not supplied with sensitive nerves. They may be cut, or sawed, or gouged, both in health or disease, with very little pain, as every surgeon knows. The pain that is felt in certain cases of disease comes from the pressure of exuded matter involving nervous filaments in their periostial coverings, rather than from the substance of the bone itself, and so also of cartilage.

There can be no part of the horn, therefore, above its base, that is sensitive or painful in the operation of sawing it off, except a thin circular layer between its outer shell and the inner bone. This layer is formed by the corium or true skiu (its outer division forming the shell), united to the periostial covering of the bone, and probably in no case exceeds one-eight of an inch in thick- 
ness. It is the only part of the horn supplied with nerves, and it is supplied from the same source that supplics the skin and muscles of the forehead and temples, viz.: from the supra orbital branch of the opthalmic nerve, which itself is a division of the fifth pair, with perhaps some terminal filaments of the facial nerve. Of course the division of this tract must cause some pain, but there is no reason to suppose that it is any greater, if as great, as that caused by a section to the same extent of the same nerves in the slin of the forehead. The sensitive surface exposed in sawing off a horn three inches in diameter does not exceed one and one-eiglit square inches $\left(3 \times 3=9 \times 1_{8}=11 / 8\right)$ of a cross-cut section, that is always less painful than where the terminal ends of nerves are left exposed or inflamed, as in branding with hot irons, to say nothing of the much greater surfaca involved in the latter operation.

No nerves can reach the interior of the horn from the nasal cavities for the reason that there is no communication between the two until after the age when the frontal sinus becomes developed and the apophysis, first of cartilage and then of bone that forms the central horn, begins to atrophy to form these cavities. That button of cartilage in the calf that eventually forms the horn is cntirely separate from the frontal bone, and only becomes joined to it by age. Its imperfect or arrested development gives origin to the breed of mulley cattle-cattle without horns.

Now, the arrest of development in any special organ, so general as to become a race characteristic, is regarded among naturalists as proof that the part so arrested was neither highly organized, important, nor even necessary to the animal. The inference is unavoidable that the part suppressed could never have been highly endowed with nerves, or it never could have been suppressed. Nature does not make mistakes of this kind.

We have saicl that the nerves of the horn come from the same source as that which supplies the skin of the forehead. There is no other source from which they can be derived. The sensibility of the horn, therefore, can not be greater than the sensibility of the forehead, but, on the other hand, it may be greatly below it, owing to the diminished supply of terminal nerves. On this point no proof can be offered, because, so far as I know, no actual demonstration of nerves within the horn has ever been made; they are assumed to exist by anaiogy only.

The skin is more freely supplied with nerves than any other part of the body, and it is the part most sensitive to pain, but even this varies in different situations, and is by no means uniform. A surface denuded or inflamed is painful in proportion to its extent; but if the same surface is at once covered up and protected from the air, the pain becomes comparatively slight. It is not so much the violence, the laceration, the local injury, as its exposure to the 
air afterwards that renders it painful; and out of our knowledge of this fact has grown up the modern method of treating burns, scalds and similar injuries, by covering them with impervious coverings.

J. B. Cutts, M. D.

Geneseo, Ill., Jan. 31, 1886.

Let me now repeat, for emphasis. The bovine has a suture in the skull bones from the nose to the top of the head, and a blow on the horn tends to divide one-half the head from the other, thus springing the parts over the brain, and causing congestion and consequent agony. Therefore, it is true that when a brute knocks off the horn, either entire or only the shell, the pain is more at the center of the head (the center of the suture) than on the sides or at the horn itself. Hence, in knocking off a horn the animal will frequently, in fact almost always, show great pain, sometimes fainting and falling, sometimes (rarely) even dying. In dehorning no such scenes or consequences follow, because there is no pain at the center of the head, that is, at the brain (direct). So we almost always see the dehorned animal turn and go to eating at once; see it directly chew the cud; see it perform all the functions of the body without the slightest uneasiness or indisposition, even to instances of copulation; and of thousands that the writer has dehorned he never saw one show subsequent sickness, loss of appetite or other trouble in consequence of the operation.

The saw the writer uses is a pointed tool, so made as to operate at the very place, to prevent bleeding or growth of horn afterwards.

On this depends the whole operation. The gouge for calves works automatically, and it takes but a moment to make a mulley of any calf.

By addressing the writer at Atkinson, Ill., both these tools will be furnished at a low price. 


\section{CHAPTER V. \\ HOW TO DEHORN CATTLE.}

The accompanying illustrations, and the description of the different processes, need to be studied in connection with living subjects.

In dehorning, as we have seen, the only pain inflicted in cutting. off the horn is in dividing the periosteum, or thin membrane around the bone-horn.

Now, in young animals this membrane is more tender, and is thicker, too, than in older brutes. Hence it follows, and it is true as a general rule, the older the brute the less pain in operating, depending upon the breed of the animal and the size of the horn. All Hereford cattle, as a rule, suffer more in dehorning than Shorthorns, for obvious reasons. They have bigger horns. There are cattle whose horns hang loose. Cut the skin, and the horn drops off. No more pain is inflicted on one whose horn stands firm, for the reason that this membrane, or periosteum is cnly an extension of the skin-nothing more.

1. To operate, then, let us begin with a calf. Open the gouge, and place it upon the embryo horn. You can feel it loose on the top of the frontal bone. Press down and gouge out this embryo with the gouge: that is all there is of the operation to the calf. One crack of the gouge, and you are done.

2. If the calf has developed the horn so that it is too large to use the gouge, resort must be had to the saw; and it is well to recollect that the embryo horn has but recently begun to grow onto or attach to the frontal bone. Now, we must reach the bottom of this embryo horn, or button, and we must therefore saw in a gouging way. Do not be afraid. You are two inches above the brain in a six months' calf, and in a six-year-old you are twice that distance. As you will note, the saw is made to gouge with. Cut well down. The hair is growing on the yearling's horn: perhaps, cut away below that. Use 
your judgment. Try the horn. It is loose; it "wriggles." Well, cut away down where that wriggling takes place. It may take a little hair; no matter.

The operation is most severe on a yearling, but I never fail, and you need not. You want a "job," and you do not want unsightly stubs after a few weeks. Pray recollect that for two years a brute's horns grow very fast, after that slower, and then come the annual rings. I prefer the saw for these operations, save only on calves. So, too, after a little, will you, and you will so use it that not a stub will be seen.

On older cattle, particularly on bulls, and on some steers and cows, it is difficult to tell where the matrix is. Sometimes the ring of pulpy flesh lies partially outside the hair. In this case you must cut it off, that is all, or the horn will grow. In most cases, however, the matrix lies back of the edge of the hair. A little practice will enable you to tell where.

Do not be afraid of a little blood in the case of big bulls with large horns. Go ahead with your job when your brute is secured, and you will find that the bleeding stops as soon as he is let loose. I may here say that the rapidity with which this operation is performed limits the time of healing very largely, provided the head is properly secured before starting.

Fig. 1 shows the rope used, with a ring attached. This is all that is necessary, - a half (or three-quarter) inch rope fifteen feet long. For big bulls I use a chute, or branding pen, not over two feet wide at the outlet; and I take the precaution to bind the side posts at top with a log chain. Then draw the bull's head around with the rope, and raise it up as high as possible, so as to prevent his lifting and straining. Put a post behind him, and also put one under him, forward of the penis, so as not to crush that important factor, and so as to prevent his majesty from lying down. All being now ready, and posts in front, of course, so that he can not move, saw away close to the hair, or close to the matrix, wherever that may be. Fear nothing. Be sure you are right and blaze away. Turn him loose when done. If the second horn bothers to get at, turn the head 


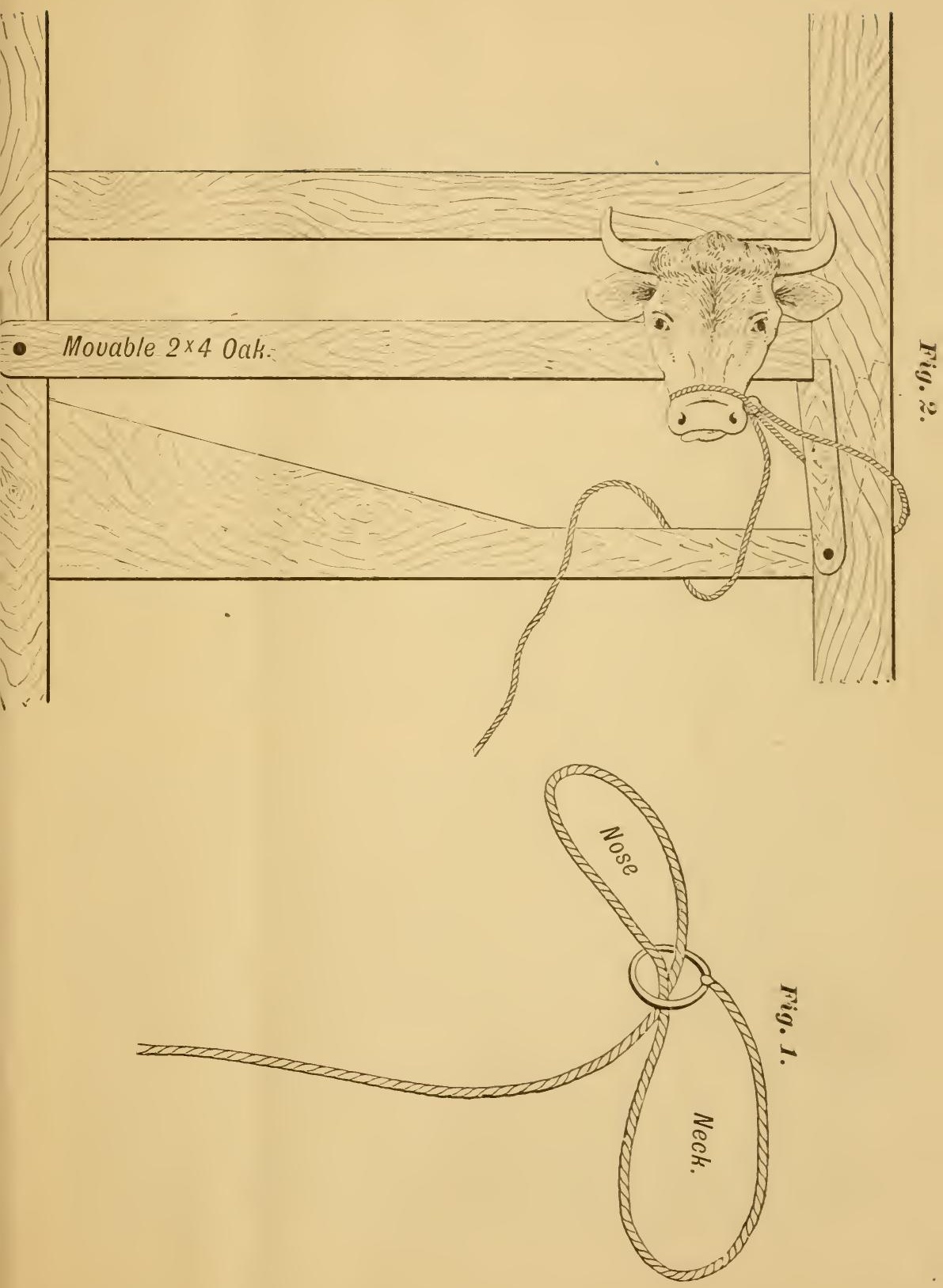


around, and tie up again. The place for the ring is under the jaw, and not so far down on the nose, as to shut his wind off. This is no child's play: it is business. He must breathe, he must be held secure; and it can be done with care, and your man-killer rendered much more safe, and no harm done to his usefulness. Use a four-inch ring.

For your herd of cows and steers, etc., use a lot of stanchions. (See post.) A little experience, and you will walk through a dozen stanchions in a very few minutes. Turn your cattle loose as fast as dehorned. There will be trouble if you do not; they will bruise themselves badly.

Frequently it becomes necessary to let down the head after one horn is cut off, and tie up again. Examine each horn before operating, and shortly you will tell at first touch just where to cut. The writer has dehorned cows very near calving, and without trouble or loss. The whole secret lies in proper stanchions, and in raising the head away up so that, when the brute falls, she hangs by the neck, and falls on the hip. Don't fear about her neck. Did you ever puli a brute out of the ditch? Well, did you succeed in drawing off her head? No, I guess not either. That is my plan; and how barl results can follow is not apparent.

In dehorning in fly time, daub the hair, not the sore, with a little pine tar, and use very little cotton and tar, or carbolic acid diluted, to put into the opening (the frontal sinus). If maggots appear, poke them out with a pine stick, and use a little (not too much) cotton moistened with turpentine. A lot of pitch pine is best of all.

Dehorn at any time of the year, save in fly time, is a good general rule. The writer pays little attention to his own rule, defying flies as well as zero. He dehorned a hundred steers once with the mercury at fifteen below zero, and no bad effects followerl.

Fig. 2 shows a rope and a four-inch ring, as it is put onto the brute. Put the rope orer the brute's neck. Take hold of the ring below, and double the rope through the ring, and now draw the loop over the nose; throw the rope up and over the top of the stanchion, a little to one side. Have your attendants raise the head, as before directed, and draw up on the rope tight. The head is now up 
and to one side. Put the rope through the ring again and bind around the bar. Have one attendant hold the rope and you saw away. If you can reach the second horn, all right; if not, let down the head and turn it, proceeding as before clirected. I repeat for emphasis.

It has been, and doubtless will be charged again, that this is a move in the interest of polled cattle. The writer is of the opinion that our polled cattle are able to take care of themselves; and he is also of opinion that we can never afford to do away with our Shorthorn, Hereford, or Holstein breeds of cattle. If his theory is right, we may in a few generations have all of these breeds minus the horns. There are men already at this very thing among the Holstein breeders, for there is a demand for a dairy cow without horns.

The question is asked if the lack of horns afrects the price of steers or fat cattle on the great markets. Put on plenty of flesh and your mulley steers will not go begging for buyers. Several times already parties who have bought cattle of the writer and fattened them have been heard to say: "We never saw cattle take on flesh as they did;" and in one instance on the same day my cattle, of a similar descruption, brought $\tilde{5}$ cents per hundred inore than a similar kind with horns, for they were fatter-all on grass.

The testimony of C. T. Powell, Esq., of $\mathrm{O}=\mathrm{co}$, in the trial referred to, was that he found $\mathrm{my}$ dehorned cattle in April in better condition on hay alone than his own cattle were on all the timothy hay they could eat, and some corn every day. There is no mistaking the point, as one year's experience will satisfy the most incredulous person. At the trial mentioned, it was amusing to hear the raried experience of different men. Our Bill Arnett swore that during the then prevailing blizzard he had put his herd of Shorthorn cattle, numbering seventy-five, into a large barn, and that in the morning he found all but eight outside, and his barn half torn down. That he believed dehorning to be a blessing and a humanity, and, as soon as the trial was over he would (and he (lid) dehorn his whole herd.

Messrs. Gilbert and Taber, who with several others took up their residence at Geneseo, "to see this thing through," testified 
in a similar strain. Mr. T. dehorned his entire herd of one hundred Holsteins. Juo. L. Jennings froze his face in coming eighteen miles to testify, and he brought down the house describing his dehorning a three-year-old heifer that came for him: "She made a dive at me, and I put out my hand to save myself, and caught her by the horn, and she went right aloing and left the horn in my hand." (He is nearly seven feet tall, and strong in proportion.)

E. C. Gilbert testified that, in his opinion, the pain, as compared with that in castration, was "as a drop of water to a bucketful." Drs. Hughes and Withers, and also Drs. McKillop and Casewell, testified that, in our climate, dehorning is a merey. The last named is the veterinary surgeon of the State. The first two are of the veterinary college, at Chicago, while Dr. McKillop enjoys a big veterinary practice on Wabash Avenue, in Chicago.

The worst possible case that the writer can conceive of occurred in his experience at LaFayette, Ind. Mr. Heath of that city, a banker and influential citizen, invited the writer to go down to his place and operate on a lot of thoroughbred and grade Hereford bulls, -all stabled and having little or no exercise, and one of them had horns of nearly five inches diameter at the place of cutting. There was no trouble in the dehorning.

In conclusion, the writer desires to express his thanks to so many good men who have been willing to take his word, and test this thing on the strength of his word alone. He trusts and believes that no bad results will follow. It is an especial matter of pride to recommend, to the readers of this book, the Chicago Veterinary College and the professors above named, and also Dr. Baker, who is a convert to dehorning by force of circumstances, and who does not, like some we know of, set up his dictum against the world. Young men and their associates, some of them, are leaving the farm in winter, and spending three or four mo:ths at this school. Go and do likewise; you will never regret it. We need to post our boys. We need good veterinary surgeons. The days of the "hoss doctor" ought to end soon. A fair knowledge of veterinary science may be obtained in two winters, and it is useful on the farm. Try it. 


\section{CHAPTER VI. \\ CASTRATION OF BULLS.}

The usual mode of castration, by cutting off the bottom of the scrotum (bag) is open to the objection that the animal does not show up as well when fat. There is no need to cut off the scrotum at all.

My method is this: On calves.-Turn the calf on his back. Let a couple of attendants hold his legs, cut the testicle open on the front side (side towards the head). This needs one cut to each seed. The entire testicle should be cut from top to bottom. I use a small, sharp knife and put the point at place of beginning, and cut clear down at one gash. Then pinch out the substance of the testicle, return the cord and muscle to their place, and the operation is done. The first cut should divide the muscle and epididymis above the seed, and, if it does not do so, why, use the knife again, and cut them down lengthwise. Do not cut them off. The object is to prevent severing cord and muscle, to be returned up into the body, and there to bleed and produce death by internal hemorrhage, as sometimes results from severing cord and muscle.

Put larger bulls into a chute, and put up a bar behind to avoid kicking. Grasp the scrotum with the left hand; turn the front side around to you; drive your knife into the top of the scrotum, and at one gash cut clear down to the bottom, and away clear through the seed; and if the epididymis and muscle are not cut, proceed to cut them lengthwise, that is down, but not off. The object is, as stated, to avoid internal hemorrhage. Peritoneal inflammation often occurs with abrasion of the cord and muscle.

The writer has never known trouble to follow this mode, save in a single instance, and he is inclined to charge that to lack of exercise before and after castration, and to drawing the cord too much during the operation. Returning from the operation last named, and 


\section{8}

hearing of the trouble, he took twelve yearlings of his own and tried part each way, with less inflammation in his new mode, as, it would seem, might have been expected. "Won't they be proud?" says one. I think not, for the epididymis is severed-I give the idea for what it is worth. It would certainly seem that this mode aroids all possible danger of internal hemorrhage. Frequently older bulls show healing by "first intention." To prevent this, and subsequent danger from pus, I put in a small string of tow cord to keep a vent open. 


\section{CHAPTER VII.}

\section{SHEDS AND WATER.}

I do wish I could make my readers all feel and know how easy it is to provide warm, tight sheds, boarded all around, and warm water insicle for the cattle that are dehorned. You are often bothered about getting your cattle through the winter, and you sometimes meet with loss. There are sheds, but they "won't go into them." They will, though, if they all lose their horns.

Now, then, let us suppose that you have 100 cattle to winter. Well, a shed $30 \times 80$ is ample for all, and a big water-tank beside. Now find a steep hillside, say a slope of one foot in five. Set eightfoot posts one foot into the ground, and eight feet apart each way; nail fence boards at the top on each side of all the posts to lay the roof boards on.

The slope of the hill makes the slope of the roof. Board up all around the outside, leaving two eight-foot openings on the south. Double board the ends on each side of the posts, and fill in the space with dry cow manure. Do same with north side. A single course of boards is enough on the south side. Lay a course of boards for the roof, and batten the cracks. Of course, on the hill-top is a windmill built to fill that tank. Level the tank, and run a small pipe up through the upper side of hill for a little vent under the tank; put on bottom of your tank a patch of sheet iron, say three feet square. Excavate so as to set a lamp under. Procure one of those small kerosene stoves of Adams, Westlake \& Co., Chicago; cost, \$1.50. You will have warm water at a cost of 10 cents per day.

Your cattle will keep fat on an ordinary winter's supply of hay, and you will all say, "It saves one-quarter the hay, and all our cattle occupy the shed;" what is more, that shed is self-cleaning, and the hillside is no objection. 


\section{IN CONCLUSION.}

I wish to add, furthermore, that, if the dehorning of thousands of cattle by myself, or by others whom I have taught, with the uniform result of no injury, no loss of appetite, no loss of milk, but, on the contrary, with the verdict of more gentle, more quiet, more tractable, feed better, fat better, handle better; if this, as a general verdict, added to scores upon scores of personal allegations made by our very best farmers and cattle men during the recent spring months, "that I have tried it on a few of the bosses, and I will never winter another horn,"-if all these things go to establish and justify a practice, then it is not too much to presume that very soon, all over this land, our dairymen, our cattle feeders and our stock growers will put dehorning into general practice, as my nerghbors of two or three counties around me are now doing or have recently done. The experiments that have been tried in connection with dehorning would be justified only on the basis of the great losses we suffer and have suffered; but they are no longer necessary, for I have demonstrated this.

1st. There is a point right at the matrix where the operation can be performed safely, and any person of common intelligence can find the matrix by careful feeling at the base of the horn.

2nd. To cut a horn off at the middle or an inch or more above the base will result in terrible bleeding.

3 rd. To cut below the matrix will result similarly, and produce a very sore head.

4th. To cut at the matrix is to avoid all trouble and all danger. This is my discovery. This was my secret, and this, in view of all the facts herein presented, is warrant enough to demand the attention of every cattle man in the country.

I have produced a saw that is perfectly adapted to the operation; a gouge that dehorns calves in an instant; and a cattle tag that must 
supersede all branding everywhere; and in this last-named invention I claim to save every branded animal ten times the pain inflicted by dehorning.

I can not lay down the pen in connection with this hastily written pamphlet, without expressing my sense of obligation to the agricultural press of the land, which have, so far as I know, without exception, given the subject matter under consideration a fair hearing, and, in most instances, an unqualified approval. There may be Scribes and Pharisees among these journals, but they are of the quiet kind, who are, perchance, waiting until they are sure of a majority vote. The secular press also, so far as 1 know, voice in their agricultural departments an echo of the same approval. When such papers as the Chicago press (not to mention names) join in according a modicum of praise to an innovation so startling in its appointments, and its effects upon the brute creation, it becomes such as the writer to acknowledge his personal obligations, and ask a charitable extension of good will until the body of our farmers shall determine upon the final measure of usefulness, by a season of common experience in dehorning.

The coming fall and winter will test the matter in thousands of places where farmers are heard to declare, "we will never winter another horn." I know where the danger lies in adopting this practice. Men will too readily jump at conclusions, and dehorn cattle so that stub horns will soon appear. I have tried to avoid this danger by carefully pointing out the modus operandi of dehorning. I could fill many pages with letters on this point. I notice that a Scotchman boasts in the papers of having used shears and clipped off twentyfive horns in thirty minutes, and I add that in less than a year they all needed clipping again.

This trouble can be avoided if you will. There is less bleeding in dehorning right, and no stubs will follow.

[THE END.] 


\section{APPFINDIX.}

There are sereral questions yet in an experimental state that I had hoped to present here, and declare ready for the public. The matter of warming water for cattle is one. The matter of Tags for cattle is another. Both of these questions will find a place soon in tue agricultural papers, and will be solved in a manner satisfactory to the farmer and to stockmen.

In presenting a new edition of this little book to the farmers and stockmen of the United States, it seems the proper thing to give the present status of the art, the objections now urged, and the future outlook.

More than two thousand farmers have dehorned their cattle in the northwest alone during the fall and winter of '86. The demand for books, for tools, and for the personal presence of the author, is greater this April than at any previous time since dehorning began. Will the practice become universal? Well, time alone can determine that question. This much seems settled. No one who has tried it goes back on it. All seem to endorse it. No injury has followed. We have never heard of any loss by it. True, our friend Lan Waite, of Sycamore, dehorned a Jersey bull and the bull died, but all admit that dehorning was not the cause. If men will "go it alone" when for thirty cents they can "read and know," we do not see who but themselves is to blame. Two other instances of death have come to our notice, but in both cases igno- 
rance or carelessness was the cause. Most of our readers are like our friend Moses, of Geneseo, Ill., who says, "We dehorned our herd on our Nebraska ranch, and we would not have the horns on again for five dollars a head."

We see no reason why dehorning shall not obtain all over the land. It is certain that dehorning:

1st.-Will save 200 human lives yearly.

2nd.-200,000 cattle and horses yearly.

3rd.-Great numbers of hogs and sheep.

4th.-One-fourth the hay in winter.

5th.-One-tenth the corn to feeders.

6th.-One-half the shed room.

7th.-One-half the manure.

8th.-Nearly all loss of calves by abortion.

9th.-All loss in shipping cattle.

10th.--Profanity enough to sink a nation.

All this yearly-giving an aggregate saving in dollars and cents of over $\$ 10,000,000$ annually in Illinois alone and $\$ 100,000,000$ in the United States. If anyone has a greater or a more modern plan of benefiting the human and the brute creation, we have failed to hear of it. It was well said by one, "As I think of it, its advantages become more and more apparent, until I am astonished that I did not think of it and put it into practice years and years ago."

\section{OPPOSITION.}

But are there no opponents? Of course there are. There can be no good thing without. There is the "Champion Liar" of Henry county, and his ilk. Nothing escapes their carping, dirty slang. With no brains and less decency, they make up in noise what they lack in sense, and remind us of old Sam Johnson and the young man who said, "Well, I must live, you know." "Well," said old Sam, "I don't see much need of it."

Then, there are the Scribes and Pharisees. They don't beliere in it"Not though one rose from the dead"-no; of course not.

\footnotetext{
Wise in our own opinion, we, And wiser we don't mean to be.

Tho' seven men can render reason,

Their talk is heresy and treason.
}

Then there is that other class, who "have the gentlest bull you ever seen," and they don't believe in it, and they won't until a cold horn is run into them-when possibly it is too late. "Oh!" said one of them, "what a captious fool I was, and how it all came to me as I was lifted up and sot 
down on the fence. I'd 'a gin all my old boots and shoes then to have been a minute older." At the start another had the actual presence of mind to "lift himself right up off that horn, which was run into me more than six inches, and I don't want any more."

\section{BUT CATTLE WILL BUTT.}

True, cattle will butt, and their butting is bad, and much to be avoided; but the absence of horns will always commend itself to the thinking person. "If the head must come, let it come minus the bayonets," said another.

\section{CARVING CALVES' HORNS.}

No man can successfully dehorn calves with a penknife or jack-knife. Get the printed directions, and follow them; this knife business means more horns. Use the gouge as directed.

\section{DEHORNING WITH SHEARS.}

One man writes that he has "improved my method. 1 use shears similar to pruning shears, and the horns come off in a jiff." Yes, and they will grow on again. You cannot dehorn cattle properly with shears. Use the saw, and follow the printed directions, and no stubbs will result. The operation is so different in yearlings and two-year-old cattle than in older, that you must understand just what to do in each case, remembering that "any time but fly time" is a safe rule as to time, and remembering also that shears will damage the head.

\section{COMMENTS OF THE PRESS.}

The pioneer paper in all the discussion that has resulted during the past years is the Western Rural, and it deserves honorable mention for the free use of its pages. It has had some hard shots along with the rest of us, and has warded off the blows with its head. It is a capital medium of communication for the farm and the home. May it ever thrive. It says of the practice: "Ninetynine out of a hundred who dehorn cattle say that it is a good thing. The evidence presented has so impressed us in its favor that if we were feeding cattle for profit, in these times of low prices at least, we think we should take off the horns as quickly as we could get Mr. Haaff's saw." It says further:

\section{THE CRUELTY OF DEHORNING}

We are asked by a correspondent if it is cruel to dehorn cattle? This subject has been thoroughly discussed. We have no evidence that it is as cruel 
when properly done, as some other operations which we perform on our animals. It doubtless hurts some. But it needs to be done properly. According to Mr. Haaff's method-and his method is the only one worthy the name of method that we have yet heard of - there is very little suffering. It is amusing to see the number of people who have been dehorning cattle all their lives and whose forefathers before them dehorned, now that through MIr. Haaff and The Rural and Stockman the subject has been brought to public notice. There are so many who have been at the business, and for so many years, that we almost wonder that when Mr. Haaff got ready to dehorn, he could find a single horned animal, even a Merino ram, in the whole country. There may have been and doubtle ss were, men who sawed off horns in Great Britain, but no one prior to Mr. Haaff was able to give a reason or point out the place and manner of operating. But Mr. Haaff was the first man to do more in the way of removing horns than was done ky about such an operation as knocking off a horn with a club would be.

The latest claimant to a thirty-year experience in dehorning is a Nebraska man. He is the last man to say after the woman has killed the bear, "See what Betsy and I have done." If Mr. Haaff had dehorned cattle as this gentleman describes the method, the Illinois Humane Society would have had him dead to rights when it prosecuted him for cruelty to animals. If the method described by this gentleman were the only method, The Rural and Stockman would denounce it, first on the ground of cruelty, and second on the score of trouble. He gets the animal down, ties it, saws away, drawing blood in large quantities, frequently exposing the brain, and is compelled to cover the opening to protect the brain, etc. Then he introduces a sentence ridiculing Mr. Haaff for "introducing dehorning in the United States!" Mr. Haaff has not introduced such dehorning as that in the United States or elsewhere. The Rural and Stockman has never before given publicity to any such method. The truth is, that all that is known of scientific dehorning Mr. Haaff has taught, but we presume he will not have the slightest objection to the probably large increase of the number of dehorners. to let them tell it, especially if they describe their methods.

Don't draw any head down. Don't do it. And above all things, don't pat a thing into the nose to hold the animal. It is cruel and unnecessary. Lift up the head and secure as shown in cut. To which let me add this: don't bind any animal's legs in dehorning: it is cruel, and will cost you dearly if followed up.

I add the following cut from the Rural for the sake of giving Mr. Heath's letter: 


\section{LETTER FROM MR. HAAFF.}

Edtors Rural and Stockman:-I never wish to be a pioneer again. The man at the front gets all the kicks and no pension. Here is a gentleman who writes from Maize, Kan., complaining of me that I didn't answer his questions, and informing me " that you don't know it all," etc. I have written him a personal letter asking to be told again, and that I will be sure to reply. I am sorry to offend anybody, and I guess I do a good many times by my blunt ways; but it seems to me as if the dehorning question had been thoroughly discussed, and I do believe that every man who uses my saw and gouge, who gives them a fair trial and waits results, will say as Mr. Heath does, whose letter is appended hereto. I simply asked Mr. Heath, who by the by is a wealthy banker at LaFayette, Ind., to wait until he was convinced one way or the other and then write me. He owns over a thousand head of Hereford cattle, and they are good ones, too, and he is not afraid to put up bulls worth hundreds of dollars apiece and have them dehorned. One man's evidence like him ought to settle something anyhow. Here is his letter, and let me say it was written months after I saw him, and without any call by me at all, or a word more than said at parting last spring:

\section{LaFayette National Bank, LaFayette, Ind., Sepiember 28, 1886.}

H. H. HAAFF, Esq., Atkinson, Ill.-Dear Sir-I saw my dehorned cattle a few days since, for the first time since last May. It gives me much pleasure to inform you that they are doing well, and that the result of the experiment has proven highly satisfactory to me. As an evidence of my gratification over the result, I shall in a few days dehorn all my 1 resent year's calves and many of my more mature cattle. I have not considered it judicious to communicate these facts to you until every doubt upon the subject had passed from my mind. Congratulations are extended to you by reason of my thorough conversion to your theory and practice of dehorning. Respectfully yours,

JoHN W. Heath.

I do hope your readers will not allow their prejudices to stand against pocket books. Allow me to close by adding again, dehorn your cattle, young and old. You will save one-fourth your hay; one-half your shed room; onehalf your manure; all loss in shipping; all loss of calves by abortion; all loss of life to cattle, horses, sheep and hogs; all loss of human life; and, what is best of all, your own temper.

And I place after it this communication to an agricultural paper: 
DEHORNING CATTLE.

I have had experience in dehorning cattle for severa ${ }_{\star}$ years, and for those about to try it, would say I use tree-pruning shears, with which I can clip off s $_{1}$ horn up to one and one-fourth inches thick in a moment. For stock six months old and under, I let one man hold the animal's head steady with a common rope halter, another man holds the animal close to a fence or a board partition. For larger animals we have a ring in the floor to draw the rope of the halter through, and a strong stanchion to fasten more securely. When horns are more than one and one-fourth inches long the saw must be used, and certainly all stockmen will agree with me that it is highly humane to dehorn the brutes, for after the act is performed, docility reigns supreme. No master of the trough among a lot of "sore heads."

Yours truly,

Moorhead, Minn., Feb. 10, 188\%.

F. J. SCHREIBER.

Wise Mr. Schreiber, where have you had your talent buried these "several years?'

I add the following letters from the $\mathrm{W}$. R., because they are not only good but come from men-plain, every-day farmers, who do not write often for the papers:

\section{FOR DEHORNING}

Editors Rural and StockMax:-I am a farmer and don't often send in anything for publication, but when I see a man like W. J. S. talking of something that he knows so little about, and without any experience in dehorning telling how men have tortured cattle by chopping off horns, I must say a word. Mr. Ignorant claims he has had cattle fifty years and never had any horned to death or gire bloody milk, and that he kept bulls and nerer had one that was dangerous on his farm. He says he has a short-horn bull and is no more afraid of him than of a lamb. Now this may be all so, but is this the case with hundreds of other men that are handling bulls and cattle? Not long ago I purchased a short-horn bull calf for $\$ 200$. After three years he began to use his weapons, and was not to be trusted at all. Finally I traded him for another bull, but the man that I traded with was rery unfortunate, for the bull got loose in the stable and killed a fine mare on the spot, worth $\$ 150$ cash. Now, was that bull's weapon worth that? No, nor himself either. The bull I got in exchange for mine was more vicious and ugly than my former one. I would like to ask Mr. Ignorance if these bulls were lamb like? Another ugly bull we had in the pasture would bellow and paw the ground when people were going along the road. Is that lamb like? 
A few days ago a cow hooked another into the barbed fence, breaking off the wire and posts. Another ran after a colt, trying its best to catch it. Two years ago we turned some horses into the cattle yard for exercise. In a short time one fine animal, a mare, lay dead in consequence of cattle's weapons. She was worth $\$ 150$ at least. How is that for lamb like stock?

Why should this man condemn Mr. Haaff when so much good has resulted from dehorning? I consider Mr. H. has saved the country thousands of dollars every year, to say nothing of the human lives saved. To test the dehorning, we began over a year ago to saw off some of our vicious cows' horns, with very fine results. Then, afterwards, we made fast in the stanchions several head and dehorned them in a few minutes. I consider the torture to amount to nothing, not so muoh as to castrate an animal, for when let loose mine soon went to eating. Nor did the cows shrink in their milk. But how it quieted them down! Their ugly disposition had gone. No more killing horses or running after colts, no more goring calves; no more tearing down fences; no such hooking and pushing at the water trough as formerly. Now they do appear lamb like. I am not in the least fear of going before them, or close to their heads. In regard to those dehorned a year ago, the horn at the place of sawing off is healed over solid, so that no bad effects can arise from it. Let me again repeat that Mr. Haaff has been a great blessing to his country in introducing dehorning. As for me, I don't want any more horns on my place. It makes no difference how lamb like they appear. Mr. W. J. S. says God gave man dominion over the beasts of the field. That is it exactly. But could he have dominion over their weapons? Their weapons were made only for their wild state, but it belongs to man to improve on these weapons. Suppose because it hurts a little we should not castrate, but let our stock of all kinds go just as they were created, what would we have then? This dehorning is a great improvement in subduing them, as it also improves their looks. Dehorning is not going to stop.

\section{R. Hillaman,}

\section{CRUELTY TO STOCK.}

Editors Rural and Stockman:--During the past year or more, while perusing the columns of The Western Rural, I have become much interested in the subject of dehorning, as adrocated by H. H. Haaff, and it is but natural that when one's attention is called to this subject for the first time that the vision or remembrance should come before his mind of some cow or steer which he may have seen whose shell horn has been slipped, leaving the sensitive tissue which covers his bone horn exposed and bleeding profusely. With one class the subject, without investigation, is thus dropped and the ver- 
dict pronounced. Oh! cruelty. Now, while we would not approve of every advanced theory without investigation, it is not in accordance with the true enlightened idea of an American citizen to dismiss a subject without first giving it careful thought and try to arrive at an intelligent decision. Practical dehorning was new in this section of Iowa until adopted by the writer, under the instruction of Mr. Haaff. Yet the subject was familiar to the minds of an intelligent class of farmers, especially the readers of The Rural and Stockman. I find also that those who in the past have been most careful to provide for the welfare and comfort of their stock are the ones who most readily approve of dehorning. This is not strange, for when one has provided at great expense sheds for their protection, it is not pleasant to learn the fact that you have merely provided shelter for a few strong old bosses, while the weak and timid ones stand out in the storm and look in the same with the feed racks and water trough.

As an example of those who raise the cry of cruelty, I am reminded of a man of my acquaintance whose cattle had been known for a number of years by having their ears and tails frozen off from exposure. I notice sereral writers on the subject of dehorning advise their readers to "procure a good sharp saw and blaze away." Now I think such instruction is rather too brief. I would say, learn all you can conveniently from those who have giren the subject thought and have also had some practical experience. Then provide suitable ropes and tools, also stanchions properly constructed, so that the work may be done in a quiet yet expeditious manner. This is especially important when dehorning milk cows or those heavy with calf, and if the rules adrocated by the originator, Mr. Haaff, are practiced, the work may be done without even a shrinkage in milk, or any ill effects resulting The writer has now taken the horns from two hundred and fifty head, about one-third of which were milk cows, and these latter have expressed themselves so plainly through the milk pail that I am now convinced that the pain inflicted is not worth considering in comparison to the advantages resulting either from a humane or financial standpoint. I am in favor of breeding and gouging the horns from the calves, and sawing from the old cattle, and with The Rural and Stockmun I am in faror of dehorning the devil by educating the youth, and removing the horns from the intemperate by suppressing the liquor traffic, thus saving more than one-half the misery caused to man and beast as a result of horns.

B. F. R.

Dunlap, Ioroa.

The following clippings from the Furmers' Review: Another stanch friend of dehorning presents points of interest to all: Mr. H. H. Haaff attended the Wisconsin farmers' convention held at the state capital last week on iuvita- 
tion of Professor Henry and others connected with the state board. A hearing was arranged for him on Tuesday p. m. in the assembly hall, the legislature adjourning for that purpose. The hall was packed to its full capacity. of course his theme was dehorning, which he illustrated by specimens of skulls minus horns and horns minus skulls. Professor Henry's published experience in dehorning had prepared the way for a farorable reception of the plan, and judging from the reports of the meeting in the Madison papers Mr. Haaff seems to have carried everything before him, fully four hours having been taken up by his speech and subsequent reply to questions before the meeting was willing to disperse. There can be no question but dehorning has come to stay, and at no distant day will be generally practiced, but upon young calves instead of grown animals, the wearers of horns having meanwhile all disappeared.

The Reviero further adds: We think it folly to claim that the operation of dehorning cattle does not cause suffering. The real question to be considered is, "Are the advantages resulting from dehorning such as justify the infliction of whatever degree of suffering attends the operation?" There are other operations, the propriety of which no one questions, which also cause suffering to animals, such as castrating males, speying females, branding, cutting off the tails of lambs, making ear marks, etc. These operations under most conditions are regarded as necessary and so justifiable. In case of dehorning, if properly performed, we are satisfied the suffering is not as great as is claimed by many. The argument against dehorning because the animals were created with horns, would, if carried to its legitimate conclusion, prevent the castration of all male animals as an interference with nature, and if adopted and put in practice would in about three years bring about a condition of things among our domestic live stock which N. L. H. would not find it pleasant to contemplate. In this, as in many other things, prevention is better than cure, and it, is better to operate on the four-weeks-old calf, so as to prevent the growth of horns, than to let it grow up and then have a serious tussle with it to take the horns off. The comparison instituted by our correspondent between the suffering caused by taking off the horns of an animal and cutting off the ears of a human being is not a fair one. The horn is not supplied with sensitive nerves as is the ear. The only sensitive part is the thin membrane enveloping tine inner bony core, not thicker than a sheet of paper. Neither the outside horn shell nor inside bony structure are supplied with nerres, and besides the nervous system of the bovine is not as delicate and sensitive as that of the human family.

It may be said right here that the operation of dehorning is more severe on the calf than at any other age. The printed directions sent with each gouge should be carefully followed, or stubs will appear. 
The Live-Stock Indicator, of Kansas City, comes out square-toed and flatfooted, and says "horns must go." Hear it:

\section{HORNS SHOULD GO.}

The Live-Stock Indicator is thoroughly convinced that horns on cattle are a cruel and costly nuisance, which the breeders of the future have no valid, sufticient excuse for tolerating or perpetuating.

Again it says:

Henceforth farmers and stockmen will be seeking information about dehorning calres-in what manner and at what age it is best done; and the agricultural colleges and state veterinarians should be utilized as mediums for disseminating correct knowledge on the subject. The colleges raise more or less cattle and afford opportunities for giving their students ocular demonstrations of the work, while the state veterinarians should, at farmers'institutes and similar meetings, give not only brief lectures on the subject, but perform in public the operation on calves that would be brought there for that purpose.

And again:

\section{THE HORNS GOING.}

When the Live-Stock Indicator announced in a recent issue its conrictions that the "coming steer" would be hornless-and correspondingly harmJess, might have been added-it had no information that any of its western friends outside of the breeders of polled cattle had been putting the idea in practice among their calves.

But now comes Mr. P. R., of Kansas College, who is known as one of the most staunch short-horn men in the west, and announces that he began dehorning his calves last April, and has now about serenty head of muley highgrade short-horns.

Mr. K. Was in the city last week, and gare as his reasons for the practice that while in his experience with horned cattle though no serious accidents had ever been caused by them, it invariably happened that the younger and weaker animals had to be separated from the herd in order to obtain their rightful food.

And this from the United Statex Dairyman:

\section{DEHORNED, HAPPY CATTLE.}

Mr. S. West, of Boone county, Indiana, writes us that he has made a grand improvement of his Duke and Bates breeds of cattle, by taking off their horns, He says their wicked dispositions went with their horns. Besides becoming more gentle, he finds he can put them in the barn like sheep, and a much 
greater number will eat from the same trough, and they have no fear of one another. They do not seem to suffer any ill effects from the dehorning, as they produce the same amount of milk and butter as before.

And this is from a Pharisee:

The lull of the winter season has brought the annual dehorning question on the scene again. This year it is full of scientific plans and methods that sound pretty difficult and somewhat dangerous. I cannot at all understand why wholesale dehorning is necessary or advisable. It is to my eyes very disfiguring, and I have not found horns any disadvantage in a rather long career of handling both beef and thoroughbred cattle. Sometimes a cow is bossy and her spirit has to be curbed. But is it requisite to visit her sins upon the whole race? Now I have found that simply to saw off the tips of the horns of a bossy animal suffices to curb its spirit. Amnng short-horns we find such a large proportion of incurving horns that their owners can never be at all dangerous to anything, and this character of horn is always a great ornament. To sacrifice it in calfhood, before it has shown how it will grow, appears to me to be a piece of unnecessary vandalism, on feeding cattle almost as much as breeding stock.

Capital growler, aint he?

And now comes another. This time a regular old rip-snifter. This man is a knowist, the editor of the so-called "Short.Horn Journal," of Ky. Listen, while he speaks:

\section{THE DISHORNING CRAZE.}

Some of our constituents have requested that we attack this dishorning foolishness that interested persons are trying to make a craze to help hornless breeds, and cause the unwary to buy them on that plea. The whole thing is too insignificant for us to dignify with an attack. One to read the articles would think that the beautiful horns that so much adorn the wearers were formidable weapons of destruction, more to be feared than the catapults of the ancients or cannon of modern times. That the poor, offenseless bull with horns is to be likened to the arch enemy of mankind who goes about seeking whom he may devour. From the amount of talk about the lack of horns we should judge that this deficiency was their greatest if not their only recommendation to the American people. Why don't they talk about their milking qualities that would recommend them to the farmer and agriculturist? Simply because they are woefully deficient in that important part of the beef animal. Why don't they bring forward the beef qualities of their favorites? Because they know they cannot compete with the short-horn in that. Now as a last resort they make a great "bugaboo" of the horn question, and spin 
long yarns about the danger of horned cattle to draw the attention of beginners to them. They remind us of the fox that accidentally lost his tail and went around among his acquaintances trying to persuade them that the loss was an adrantage; that it added to his personal beauty, and that he was better off without a tail than with one, and urging that the other foxes cut off their tails to be in the fashion. The other foxes saw through the thin artifice and told him they were satisfied with their tails and would keep them.

The short-horn men are perfectly satisfied with the horns with which their cattle are adorned. They know, too, that there is not so much danger in the thrust of the horn as the butt of the head. All who have had experience know that a blow on the abdomen of a cow is more apt to make her lose her calf than a punch. The horns scratch off the hair, possibly.

Verily ye are the people, and wisdom shall die with you. The "dishorning craze." Dishorning is gond. It is perfectly safe to assume that any man who speils it with an "S" also spells his I with a " hi" and "ails from hould Hingland." Anyone disposed to treat the language fairly will at once admit that there is no need of two consonants in the word, and that to behead and to dehorn are alike euphonious and grammatical in construction.

At the outset of this question it never occurred to the short-horn men that dehorning might become an essential to their business; but it is, nevertheless. A race of short-horns that are without horns are the only cattle that can hold the fight as against the black cattle. In the opinion of the writer the farmers will have muley cattle somehow, and the idiot who penned the above drizzle will live to see the truth of my proposition if Providence should spare his unprofitable life for ten years.

\section{A NOVEL OBJECTION TO DEHORNING.}

Mr. John Boyd, the Jersey breeder, in a communication to Hoard's Dairyman, takes issue with Prof. Henry on the subject of dehorning, especially of dehorning Jersey hulls, which he objects to, not on the ground of cruelty, but because he believes it will destroy the usefulness of the animal. His theory, which he admits is as yet unsupported by facts, is that by depriving the animal of his means of offense and defense, and breaking down his courage so that, as admitted by Prof. Henry, his dehorned six-year-old bull was after a short tussle mastered by a two-year-old yet bearing his horns, there is danger that his prepotency will be destroyed, so that he will no longer impress his

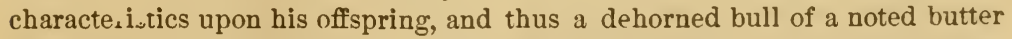
line of descent will become no more valuable as a getter of butter cows than an ordinary bull of the same breed. Further on in the article he declares as another ground of objection to dehorning, that the "hornless cattle are prob- 
ably the worst fighters in the world, and actually do more damage to one another than those furnished with the weapons nature gives them." This declaration is certainly open to question. But admitting its correctness, it naturally follows that the dehorned bull, instead of remaining a broken spirited animal, speedily becomes a better fighter than ever, so that instead of losing his prepotency, this quality would be increased.

As I have written in the Reviero - "there is nothing to the point made in the Dairyman." Old Dauphin 20th has given us three crops of calves, since being dehorned. He is six or seven years old, and is as prepotent and as good a getter as before being dehorned.

The Breeders' Gazette at Chicago is the live stock journal of the Northwest. It is king of the crowd, and it was a great surprise to the writer to find its Mr. Dickenson reporting the Wisconsin address to the length of several columns. It is tony, perhaps, and feels its oats (ads), but it has been very fair in this discussion, riding no high horse at all.

Here comes a screamer from the North Pole, away up in Dakota :

To-day I cut off four sets horns, and the old cows did not care much, but, oh, do tell me quick. I cut off a four-year-old steer's horns (half Jersey blood), and oh! Oh-I guess he will die. He bleeds awful, say six hours, a fine stream, squirting four feet. We are now trying to stop the blood, and don't know how. Now write me a private letter, and tell about such cases. The cows hardly bleed any, but think of this steer bleeding after nine hours, and still at it. Do they ever die? How to stop the blond? I certainly shall not dare to cut off any more till I hear from you. He bleeds on the right stub, not on the left. How much blood has a steer, and how long will it take a single fine stream to bleed an animal to death ? Do answer quick.

\section{COMMENTS.}

All that ails this steer is that first he was hot when dehorned; second, the horns were not removed; stubs were left, which of course bleed.

The printed directions which go with the tools will, if followed, save such experiences.

The Farm, Stock and Home, of Minneapolis, Minn., says of dehorning: We advise our readers to "go and do likewise." We have heard from and conversed with a great many who have dehorned their stock and have never heard word of regret, nor an intimation of any ill effects; on the contrary the expressions were uniformly those of satisfaction and delight. 
H. H. HaAFF, Esq.:

Dear Sir: As a reader of my paper you cannot be in any doubt concerning my opinion of the beneficial effects of dehorning. I have published many letters from those of my readers who have dehorned their cattle, those who were inexperienced, who never saw the work done, yet their success was so complete, and their satisfaction orer the results so entire, that they would hasten to assure.

Minneapolis, Minn., March 18, 1887.

Friend HAAFF:

I have been dehorning for some time. When I commenced prejudice was largely against dehorning, but it has given way, and dehorning is very popular here. I have dehorned old bulls and young ones, cows of all ages, in all kinds of weather and in every condition. Many calls to see our herd of polled short horned cattle. In all our experience we never had an accident, nor have we seen any bad results. Would advise all to dehorn their cattle and save shedroom, feed and accidents.

D. II. Clark.

New York, Iorca. 1882.

No better authority in Iowa on farm topics than this man.

The following letter from Professor Henry shows the manliness of the man. When he believes in a thing he knows it, and is not afraid to let his light shine. Contrast his course with that of Professor "day after to" Morrow at our hermaphrodite institution at Champaign. Over a year ago Professor Morrow heard all about dehorning at Princton, Ill. He took notes at the institute then of my two hours' talk. Asked questions and seemed interested; made no objections whatever, and yet I have to hear of the first utterance since from his mouth. But with Professor Henry how different. He has no politics in his Fears nothing. Cares only for truth. Is not a political professor. Teaches and talks what he believes. He got right up before seren hundred people and said out and out, "Dehorning is right, and you don't want to let your prejudice overbalance your judgment." The one is a man. The other I deem a milk sop. The one has a big agricultural department, while the President of the Board of Agriculture of Illinois says he was down to Champaign, and the other had five pupils taking an agricultural course. Comment is unnecessary.

\section{PROF. HENRY SAYS:}

Dear Mr. Haaff:-I have just one point I wish to make in this matter of dehorning cattle. In spite of all the talk against it, based upon every conceivable assumption, I have yet to learn of the first person saying a word against the practice voho knevo anything about it by direct observation. On 
the other hand I hare yet to hear of the first person who practiced dehorning and was not pleased and satisfied with its workings. Let those who are so loud with protests bring evidence and not words, and may be the farmers will listen more attentively to them; until they do, dehorning goes on.

W. A. HeNre,

Director Expl. Station, Madison.

Here comes an unsolicited testimonial, and he, too, is not afraid:

H. H. HAAFF :

Dear Sir: Your name will ever be remembered by the more humane class of stockmen as that of one who has, through great tribulation, done more to alleviate the suffering of domestic animals than any other man of this generation. Ten years will not elapse until laws will be passed prohibiting cattle with horns from running at large upon our highways, and more especially in our villages where the lives of our children are constantly endangered by those useless appendages. Trusting that you will wear with grace the honor to which you are entitled, as with courage you bore persecution in the past, is the sincere wish of yours, etc.,

Dunlap, Iowa, Warch 30, '8\%.

B. F. Roberts.

To further prolong this testimony will be useless. The Ohio Farmer writes a personal letter, adding its powerful weight to the affirmative side. The Rural New Yorker, the New England Farmer, the Kansas Farmer, Phil Cheros' Paper, at St. Louis; the Omaha Bee, the Cleveland Plain Dealerwell, I might keep on giving names ad libitum of papers found advocating, some of them even declaring the writer entitled to great personal consideration " as a public benefactor",-all of which is not hard to take ; but yet, above all, it remains to be remembered that the public good is the great end to be sought, and, therefore, the reader should test the matter for himself. One man who has seven cheese factories and 3,500 cows is preparing to set the example in Old Penn, because, as he says, "the more I feed my cows and the better care I take of them, the worse they are."

Another down-easter writes: "I had to keep my cattle in five different lots before dehorning them, but afterwards they were altogether, and not only did better, but it was not much more trouble to tend them all than one of the five lots before." Another is so pleased to think that, "as the animal has no apprehension of what is going to be done, the actual suffering is only momentary, and there is no dreading the operation."

My boys laugh at the matter of cruelty, and make a lot muleys right shortly after driving cattle home. A little practice and plenty of help to draw up the head, using two rings, as explained in the "printed directions," is all that is 
needed. For two and one half dollars every man may and should become his own operator.

No thanks to the Humane Society that collects fines and puts them iuto its own pocket, and no thanks to the old fossil Board of Agriculture-the selfpropagating board that is looking out for paps and political plunder, and what the Tribune calls "self-perpetuating." For all of this tribe of old barnacles dehorning will win, and the day is not very remote when horned cattle will be the exception.

\section{DEHORNING CATTLE-FULL DIRECTIONS.}

Turn the cut sidewise to look at it. Study the loops, and note before using how easily you can unlimber the animal's head. How easily you can haul up the rope taut. Use a good three-quarters manilla rope, fifteen feet long, and braid two three-inch rings into one end. The stanchion is simply an oldfashioned stanchion, only it is five feet up and down in the clear, that is between sill and top rail. Notice in the cut that the head is only partly drawn up. The cut should show a man standing in front and raising the head, and not less than two men at work at the rope. Raise and draw up very tight. Bind the rope over the top rail and nose again and through the second ring to keep it in place. Now get the saw, take your knife and shave back the hair on top so that the saw blade will not clog. You will now begin to see why Mr. Haaff's saw is better than any other for this purpose. You can cut any turn and to any point with it, which is very necessary. Some knowing critter writes the Breeders' Gazette, and the Furm, Field \& Stockman copies it as follows: "Cut three-quarters of an inch back into the hair." Well, all I have to say is don't do it. If you do you will have a lot of heads that won't heal up the bone, that's all. For cattle three years old, cut into the edge of the matrix which you expose with your knife. On older cattle don't cut into the flesh any more than to make it sore, so that it will heal and granulate properly. On two-year-olds cut a quarter of an inch into the matrix, and in yearlings cut half inch. A little practice and you will get easy and like the job, for it is a positive kindness to the animal. The party abore named has, it is safe to say, read my book, and struck out alone, and like the man who uses pruning shears, he will have to live and learn.

\section{DEHORNING CALVES}

This is tedious, serere and tiresome to man and beast. It cannot be done rightly without using the gouge, and once you have tried you will see the point. It needs four good men to dehorn calves. Throw the calf on to its back, two men hold the legs, one man the head and one operates. Now ready! 
Well, take a sharp knife and cut one-half inch deep clear around the young horn, now use the gouge and you will lift out a horn every time. Examine the embryo when removed from the gouge and see for yourself. Now try it on with a knife alone. Pick away a piece at a time, and lo! wheu the thing is done and healed up there appears a Nanny horn, a nub on one side and a scale on the other. Reason? You need a tool adapted to the purpose so as to lift the whole embryo out bodily; any part left lives and will grow. I may here say that I have had an unlimited amount of trouble to get my tools made to suit me. I have made enemies of the manufacturers because I was so particular, and enemies of some who "order and don't receive," but all that is over now. My tools are malleable iron, will stand rough work, and dehorning is no child's-play. When it comes to be understood all will agree that I have produced tools that are adapted to the business, and a saw tha is better for the kitchen than any now made. I am charged with seeking to make money, etc., of course. That is the "fly in the ointment," and we wouldn't be in this world if those flings were lacking. The tools are O. K., and cheap, an i. that is enough to say.

\section{What the Western Rural says :-}

"A correspondent writes: I have read every article in your paper during the last two years that had the word dehorn in it. I spent two hours with Mr. Haaff last year in your city, and learned what I could. Bought his saw, came home and went to dehorning my stock. Succeeded satisfactorily, and to-day the most of our farmers have their stock dehorned. We are all pleased and delighted, and hare long since stopped discussing the subject of dehorning, but consider it a fixed fact. But to-day when I read in my paper how a correspondent did his dehorning, and could dehorn nine an hour, I laughed, fo: myself and four men dehorned sixty-eight head of two-year-old steers last fall in two hours and one-half."

Since the above was in print I have lost my not by the operation of dehorning, but by injury received by using a Chute. No more Chutes for dehorning. Use only the stanchion, as pictured in the cut.

$$
\text { H. II. HAAFF. }
$$



PBC

Faikuaw pogers

636.2083

$H 116$ 


\section{(2)}

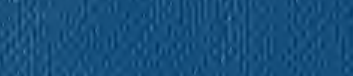

\section{0 (}

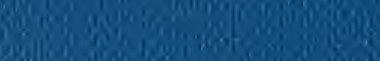

860)

$$
\text { 20. }
$$

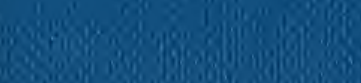

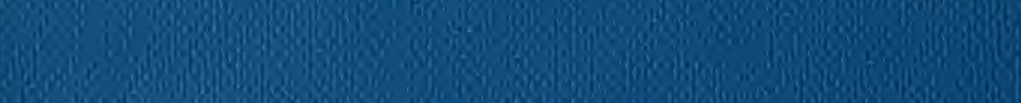

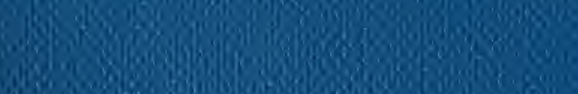

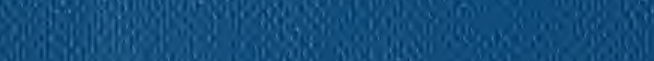

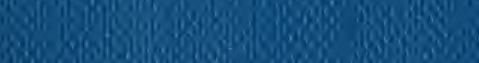

380.

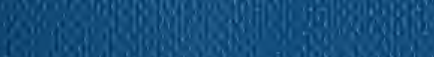

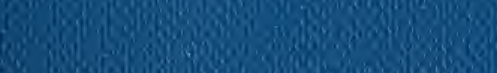

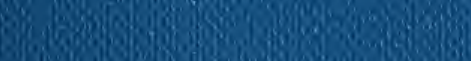

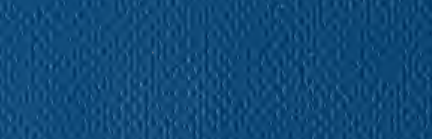

